\title{
PERKEMBANGAN INDIKATOR MAKRO EKONOMI KOTA BANDUNG KUARTA II-2019
}

\author{
Teguh Santoso ${ }^{1}$ \\ Bayu Kharisma ${ }^{2}$
}

\author{
Fakultas Ekonomi dan Bisnis Universitas Padjadjaran, Jawa Barat, Indonesia ${ }^{1,2}$ \\ Email: teguh.santoso@unpad.ac.id ${ }^{1}$
}

\begin{abstract}
Analysis of the development of macroeconomic indicators is commonly done as an evaluation material and economic management strategy in the future. There are 3 macroeconomic indicators that are commonly used at the regional level, namely the rate of inflation, economic growth and employment. This study aims to conduct an analysis of the three indicators at the Bandung City level. The research method used is descriptive and quantitative analysis. Descriptive analysis is based on the movement of data presented through graphs and tables. While quantitative analysis is more focused on calculating the inflation variable projections and correlation analysis between macroeconomic variables. Based on the results of descriptive analysis, it is known that the Bandung City inflation indicator was relatively maintained in the second quarter of 2019. Even though there is a moment of Eid, the inflation rate is still under control, and even tends to decrease in June 2019. However, the inflation rate is predicted to increase in the third quarter of 2019. Food commodity inflation is predicted to occur due to the peak of the dry season in August-September. On the indicator of the rate of economic growth, the most recent data for 2017 shows a decline in the growth rate, by $7.21 \%$. The achievement of economic growth is also the lowest since 2011. On the employment indicator, there is an irrelevant relationship between the Economic Growth Rate (LPE) Labor Force Participation Rate (TPAK), and the Open Growth Rate
\end{abstract}

Keywords: Inflation; Economic growth; Employment Bandung.

\begin{abstract}
ABSTRAK
Analisis perkembangan indikator makro ekonomi lazim dilakukan sebagai bahan evaluasi dan strategi pengelolaan perekonomian di masa yang akan datang. Terdapat 3 indikator makro ekonomi yang lazim digunakan dalam tataran regional, yakni laju inflasi, pertumbuhan ekonomi dan ketenagakerjaan. Kajian ini bertujuan untuk melakukana analisis terhadap ketiga indikator tersebut pada level Kota Bandung. Metode penelitian yang digunakan adalah analisis deskriptif dan kuantitatif. Analisis deskriptif didasarkan pada pergerakan data yang disajikan melalui grafik dan tabel. Sementara analisis kuantitatif lebih di titik beratkan pada perhitungan proyeksi variabel inflasi serta analisis korelasi antar variabel makro ekonomi. Berdasarkan hasil analisis deskriptif, diketahui bahwa indikator inflasi Kota Bandung relatif terjaga pada kuartal II-2019. Meski terdapat momen periode lebaran, namun laju inflasi masih terkendali, bahkan cenderung menurun pada Juni 2019. Namun demikian, laju inflasi diprediksi akan meningkat pada kuartal III-2019. Inflasi komoditas makanan diprediksikan akan terjadi akibat puncak musim kemarau Agustus-September nanti. Pada indikator laju pertumbuhan ekonomi, data yang terbaru tahu 2017 menunjukkan adanya penurunan laju pertumbuhan, sebesar $7.21 \%$. Capaian pertumbuhan ekonomi tersebut juga merupakan yang terendah sejak tahun 2011. Pada indikator ketenagakerjaan, terdapat hubungan yang tidak relevan antara Laju Pertumbuhan Ekonomi (LPE) Tingkat Partisipasi Angkatan Kerja (TPAK), dan Tingkat Pertumbuhan Terbuka
\end{abstract}

Kata Kunci: Inflasi; Pertumbuhan Ekonomi; Ketenagakerjaan; Kota Bandung. 


\section{PENDAHULUAN}

Analisis perkembangan indikator makro ekonomi lazim digunakan untuk melihat arah pergerakan variabel makro ekonomi baik pada level nasional maupun regional. Dengan diketahuinya arah perkembangan variabel ekonomi, maka dapat dijadikan sebagai bahan pengambilan kebijakan baik bagi Pemerintah maupun dunia usaha. Kebijakan makro ekonomi, pada dasarnya memiliki 3 (tiga) tujuan utama, yakni menjaga stabilitas harga, mencapai pertumbuhan ekonomi yang tinggi dan menciptakan lapangan kerja. Selain tentunya juga terdapat variabel makro yang penting, seperti stabilitas nilai tukar dan neraca pembayaran untuk perekonomian terbuka (Mulhearn, 1999). Namun pada level regional, hanya terdapat 3 (tiga) varibel yang dapat digunakan sebagai indikator, yakni yakni 1) inflasi; 2) pertumbuhan ekonomi dan 3) indikator-indikator ketenagakerjaan.

Bagi level daerah, dari 3 (tiga) indikator yang ada, terdapat 1 indikator yang sering menjadi sorotan dikaitkan dengan kinerja pengelolaan perekonomian daerah, yakni indikator inflasi. Tentu saja dengan tidak mengesampingkan pentingnya indikator lainnya. Inflasi di daerah menjadi salah satu kunci keberhasilan kebijakan ekonomi lokal. Pembentukan TPID juga menjadi bukti bahwa pengendalian harga merupakan hal yang harus dilakukan guna menjaga daya beli masyarakat. Bahkan pemerintah pusat memberikan penghargaan kepada daerah yang berhasil mengendalikan inflasi.

Kota Bandung memiliki tantangan tersendiri dalam pengendalian inflasi. Sebagai kota dengan populasi yang besar, bukan merupakan daerah produsen, serta 
menjadi daerah destinasi wisata dan pendidikan, maka berpotensi memiliki laju inflasi yang tinggi. Meski demikian, karakteristik Kota Bandung tersebut juga berpotensi untuk mencapai pertumbuhan ekonomi yang tinggi yang dapat meningkatkan penyerapan lapangan kerja. Dengan demikian, melihat perkembangan laju inflasi menjadi penting bagi para stakeholder di Kota Bandung. Dengan diketahuinya perkembangan laju inflasi, maka dapat digunakan sebagai dasar kebijakan ekonomi daerah periode mendatang. Selain itu, dengan melihat indikator laju pertumbuhan ekonomi dan indikator ketenagakerjaan, maka gambaran perekonomian secara Kota Bandung dapat dilihat untuk menjadi referensi bagi pengambilan kebijakan ekonomi.

Tulisan ini memiliki tujuan 1) melakukan analisis perkembangan inflasi dan proyeksinya; 2) analisis pertumbuhan ekonomi agregat, kontribusi dan pertumbuhan sektoral, 3) analisis perkembangan indikator ketenagakerjaan khususnya tingkat partisipasi angkatan kerja (TPAK) dan tingkat pengangguran terbuka (TPT), 4) analisis korelasi pertumbuhan ekonomi dan kemiskinan dan 5) analisis korelasi TPAK dan TPT dan pertumbuhan ekonomi

\section{METODE PENELITIAN}

Terdapat dua metode analisis yang digunakan dalam kajian ini. 1) metode analisis deskriptif dan 2) metode analisis kuantitatif (model ekonometrika). Dalam metode (1) teknik analisis yang digunakan adalah analisis grafik dan tabel untuk menjelaskan pergerakan indikator makroekonomi. Grafik adalah salah satu alat analisis utama dalam kajian ekonomi. Grafik berperan untuk menunjukkan hubungan variabel- variabel ekonomi secara visual (Sugiarto et al., 2007). Dalam 
kajian ini, grafik digunakan untuk menjelaskan hubungan antar indikator- indikator makro ekonomi yang secara teoritis memiliki hubungan yang erat satu sama lain. Tabel adalah model penyajian yang disusun dalam baris dan kolom. Tabel berupa kumpulan angka-angka berdasarkan kategori tertentu

Metode (2) digunakan untuk melakukan proyeksi terhadap variabel inflasi dan melihat korelasi antar variabel makro ekonomi.Data yang digunakan merupakan data sekunder yang bersumber dari Badan Pusat Statistik (BPS) Kota Bandung dan sumber lain yang relevan. Dalam melakukan proyeksi, teknik analisis yang digunakan adalah Metode Autoregressive Moving Average (ARMA) dan analisis korelasi. Model untuk ramalan laju inflasi dibuat menggunakan model BoxJenkins yang disebut dengan model Autoregressive Integrated Moving Average (ARIMA). Box dan Jenkins mempopulerkan metode yang terdiri dari 3 tahap dalam memilih model yang cocok untuk melakukan estimasi dan peramalan data runtut waktu univariat, yaitu identifikasi model, estimasi parameter, dan peramalan (Enders, 1995). Model ARIMA merupakan gabungan antara model autoregressive (AR) dan moving average (MA). Kedua model tersebut mensyaratkan data yang dianalisis bergerak disepanjang rata-ratanya yang konstan (stasioner). Jika data tidak stasioner, maka dilakukan proses stasioner data menggunakan proses diferensi.

Metode ARMA memiliki spesifikasi sebagai berikut:

Inflasi $i_{t}=\mu+\alpha_{1}$ Inflasi $_{t}+\alpha_{2}$ Inflasi $_{\mathrm{t}-1}+\ldots+\alpha_{3}$ Inflasi $_{\mathrm{t}-\mathrm{n}}+\beta_{0} \mathrm{u}_{\mathrm{t}}+\beta_{1} \mathrm{u}_{\mathrm{t}-1}+\beta_{2} \mathrm{u}_{\mathrm{t}-2}+\ldots+\beta_{\mathrm{q}} \mathrm{u}_{\mathrm{t}-\mathrm{q}}$ Dimana:

Inflasi : inflasi (y-o-y) series data bulanan 2016.1-2019.6 


\section{HASIL DAN PEMBAHASAN}

Perkembangan dan Proyeksi Inflasi. Dapat dikatakan, perkembangan inflasi di Kota Bandung pada tahun 2019 (Januari-Juni) relatif terjaga. Secara rata-rata, laju inflasi, year-on-year (y-o-y) sepanjang semester I-2019, inflasi Kota Bandung lebih rendah dibanding rata-rata laju inflasi Provinsi Jawa Barat dan Nasional. Meski sama-sama menunjukkan trend penurunan, namun penurunan laju inflasi Kota Bandung, utamanya pada periode Juni 2019 jauh lebih besar dibanding laju inflasi nasional dan Jawa Barat. Per Juni 2019, Laju inflasi Kota Bandung sebesar 2.93\%, sementara laju inflasi Provinsi Jawa Barat dan Nasional masinhg-masing sebesar $3.48 \%$ dan $3.28 \%$.

\section{Gambar 1.}

Perkembangan Laju Inflasi Kota Bandung, Jawa Barat dan Nasional

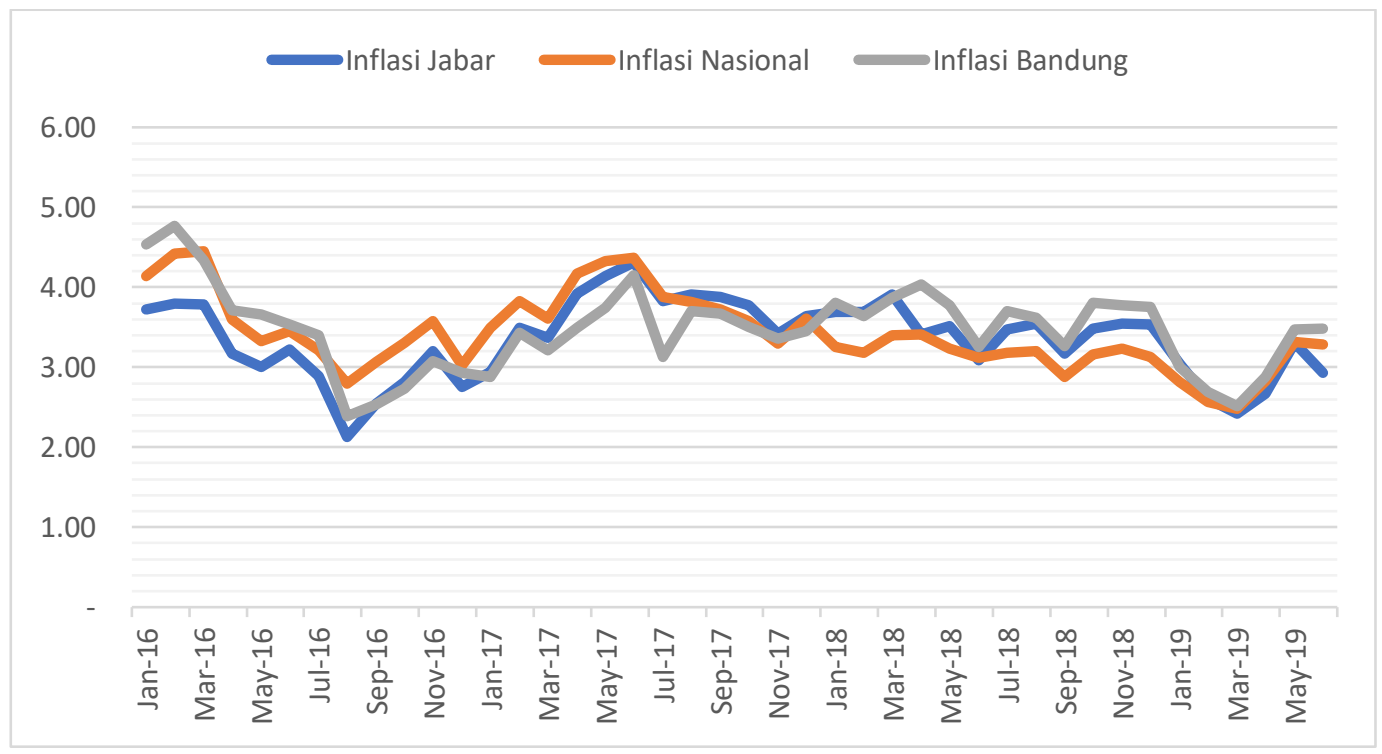

Sumber: Badan Pusat Statistik Kota Bandung, 2019, diolah. 
Selain lebih rendah dari inflasi Nasional dan Jawa Barat, capaian inflasi di Kota Bandung pada 2019 juga lebih rendah dibanding dengan beberapa Kota di Jawa Barat dengan karakteristik yang hampir sama. Kota Bekasi, Kota Bogor dan Kota Depok merupakan Kota-Kota besar di Jawa Barat dan bukan merupakan daerah produsen komoditas yang sering memicu laju inflasi, terutama komoditas bahan makanan.

Jika dilihat dari Gambar 2, terlihat bahwa inflasi Kota Bandung selama 2019 lebih rendah dibanding Kota Bekasi, Kota Depok dan Kota Bogor. Ketiga wilayah yang dekat dengan DKI Jakarta memiliki inflasi yang cenderung meningkat sejak Maret 2019. Hal ini dapat disebabkan karena wilayah-wilayah tersebut merupakan bagian dari wilayah Jabodetabek dengan populasi penduduk yang besar, sementara wilayah tersebut jauh dari wilayah penghasil komoditas pangan. Pada bulan Juni 2019, ketiga Kota tersebut juga menunjukkan trend inflasi yang meningkat, sebaliknya inflasi Kota Bandung justru menurun pada periode yang sama. Pada periode Ramadhan-Idul Fitri 2019, inflasi Kota Bandung juga lenih rendah dibanding dengan ketiga wilayah tersebut. Artinya memang inflasi di Kota Bandung relatif lebih terkendali dibanding dengan wilayah metropolitan lain, yakni Kota Bogor, Bekasi dan Depok. Namun demikian, inflasi Kota Bandung jauh lebih tinggi dibanding dengan Kota Tasikmalaya, Sukabumi dan Cirebon. 
Gambar 2.

\section{Laju Inflasi 7 Kota di Jawa Barat}

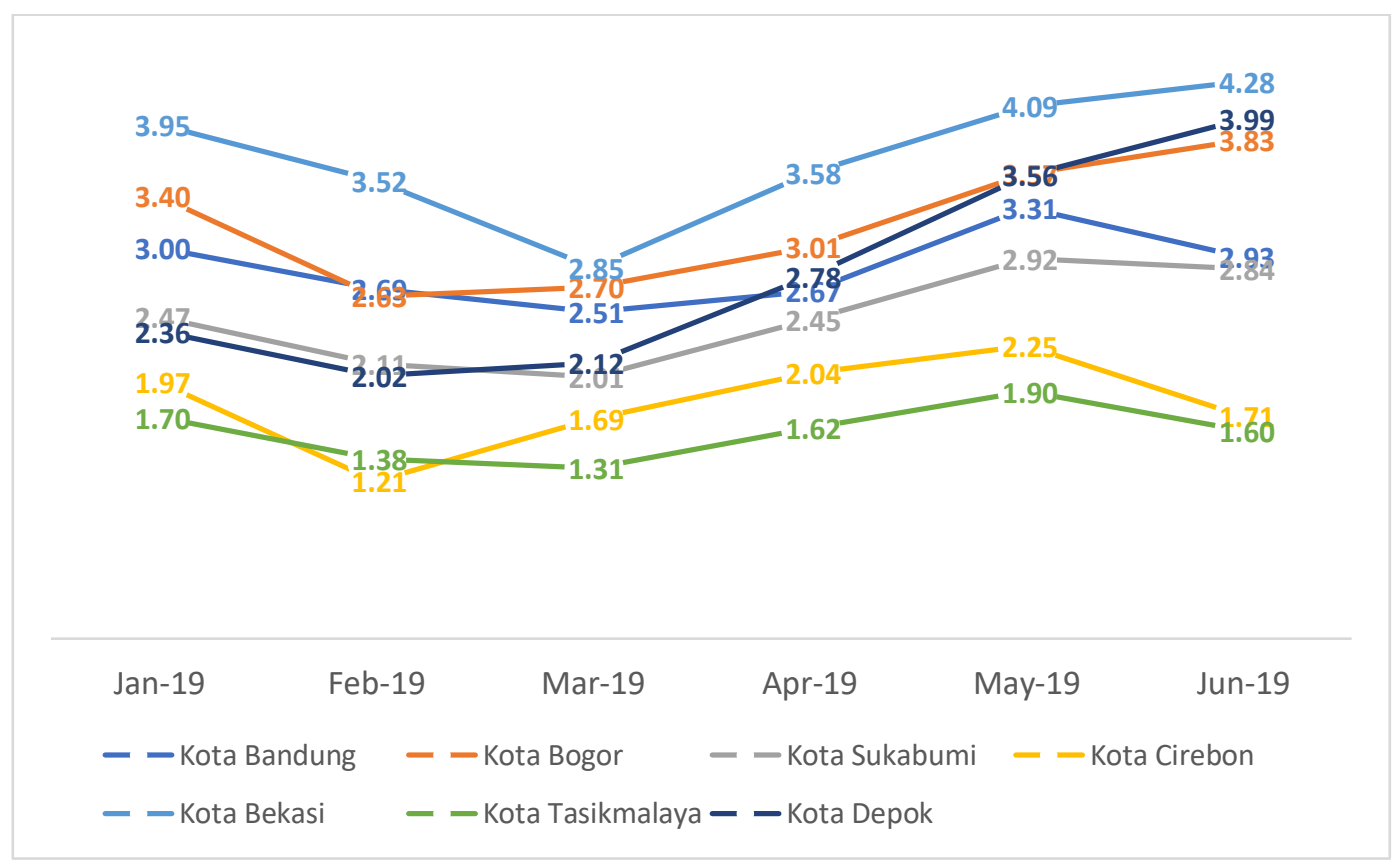

Sumber: BPS Provinsi Jawa Barat, 2019, diolah

Dari Gambar 2 juga dapat dilihat, bahwa inflasi di wilayah yang dekat dengan daerah penghasil komoditas pangan serta dengan populasi yang relatif lebih sedikit yakni Kota Sukabumi, Kota Tasikmalaya dan Kota Cirebon. Dengan demikian, terdapat indikasi bahwa jumlah pasokan komoditas dapat menjadi trigger tingginya laju inflasi di suatu wilayah, atau yang sering disebut dengan volatile food inflation.

Kota Bandung sendiri memiliki masalah dalam pengendaliana inflasi komoditas bahan makanan, meski relatif dekat dengan daerah penghasil. Pada periode Ramadhan-Idul Fitri lalu, tepatnya Mei 2019, inflasi komoditas pangan mencapai $4.01 \%$ dan menjadi salah satu kelompok pengeluaran dengan laju inflasi yang tinggi, selain kelompok sandang. 
Gambar 3.

Laju Inflasi Kota Bandung Berdasarkan Kelompok Pengeluaran.

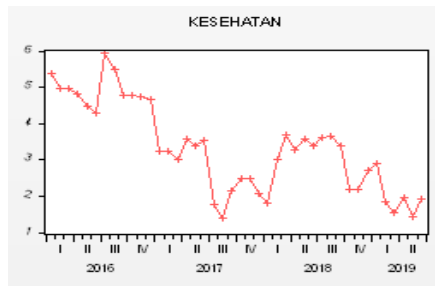

PENDIDIKAN_REKREASI_OLAHRAHGA

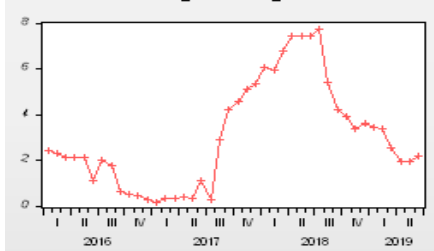

TRANSP ORT_KOMUNIKASI_JASAKEUANGAN

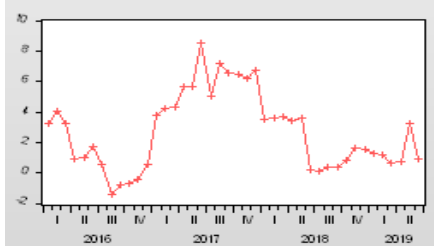

MAKANAN_MINUMAN_ROKOK_TEMBAKAU

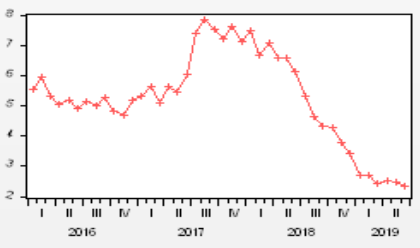

BAHAN_MAKANAN

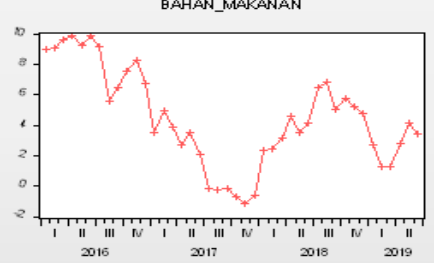

SANDANG

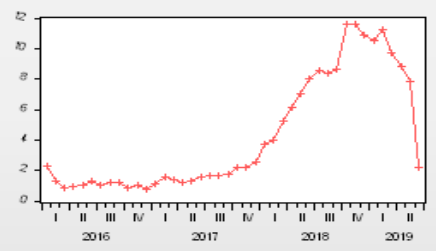

PERUMMAHAN_LISTRIKAIRGAS_BAHANBAKAR

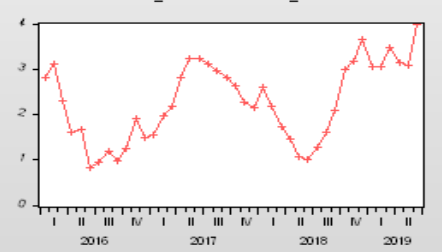

Berdasarkan Gambar 3, kelompok pengeluaran yang cenderung memiliki laju inflasi yang tinggi adalah kelompok Bahan Makanan 2) Transportasi dan 3) Perumahan Listrik Air Gas dan Bahan Bakar. Namun, pada bulan Mei yang bertepatan dengan momen Ramadhan dan Idul Fitri, hanya kelompok bahan makanan yang memiliki kenaikan laju inflasi, sedangkan kelompok pengeluaran lain justru mengalami penurunan. Hal ini menunjukkan bahwa, meski inflasi secara umum terkendali, namun Kota Bandung memiliki problematika dari sisi pengendalian harga komoditas pangan.

Melihat perkembangan harga komoditas pangan selama April-Juni 2019, komoditas bahan pangan yang cenderung berfluktuasi adalah cabe merah, cabe keriting, cabe rawit, cabe rawit hijau dan daging ayam ras dan bawang putih. Sementara komoditas yang cenderung stabil adalah telur ayam ras, , tepung terigu, 
minyak goreng curah, beras medium dan daging sapi. Khusus untuk komoditas cabe merah, sejak akhir Juni bahkan mencapai lebih dari Rp. 80 ribu/Kg. Oleh karenanya, fokus bagi Tim Pengendalian Inflasi Daerah adalah pada komoditas pangan khususnya cabai

\section{Gambar 4.}

Perkembangan Harga Komoditas Pangan Strategis Kota Bandung Januari-Juli 2019

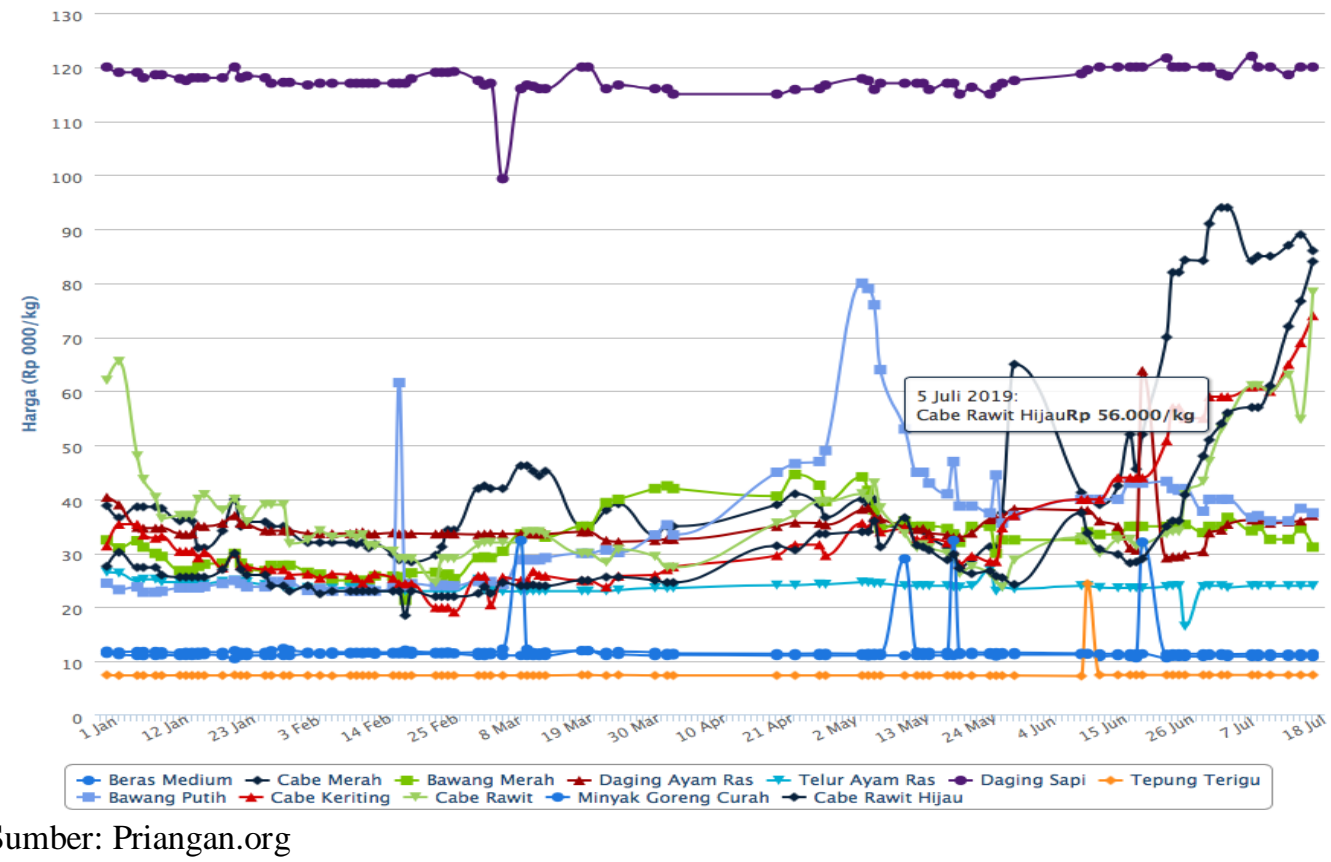

Faktor yang diduga menjadi penyebab kenaikan harga cabai adalah pasokan yang terbatas akibat musim kemarau. Namun jika dibandingkan dengan periode yang sama tahun sebelumnya, harga cabai pada awal semester II-2019 ini memang melonjak sangat signifikan. Sebagaimana disajikan dalam Gambar 4, dapat dilihat bahwa lonjakan harga cabai untuk seluruh jenis yang ada (merah, keriting, rawit, rawit hijau) jauh lebih tinggi dibanding periode yang sama tahun sebelumnya. Padahal periode yang sama tahun lalu juga pada saat musim kemarau. Patut diduga, 
terdapat faktor lain pemicu lonjakan harga cabai tersebut. Selain dari sisi pasokan, permintaan, aspek struktur pasar dan distribusi juga perlu mendapat perhatian.

Proyeksi inflasi dilakukan dengan metode autoregressive (AR), dimana inflasi pada periode proyeksi mencerminkan potret kondisi inflasi periode sebelumnya ditambah interaksi variabel kualitatif dummy dan trend pergerakan data untuk mengakomodir perilaku data periode yang sama tahun sebelumnya. Variabel dummy merupakan even seasonal yang menunjukkan perilaku pergerakan data pada saat masa puncak musim kemarau, periode Juli-Agustus dan September. Berdasarkan hasil estimasi, diketahui bahwa variabel inflasi periode sebelumnya berpengaruh positif dan signifikan terhadap pergerakan inflasi. Variabel dummy dan trend tidak memberi pengaruh yang nyata terhadap pergerakan laju inflasi. Arah hubungannya juga menunjukkan arah yang negative. Dapat diartikan bahwa pergerakan inflasi kedepan lebih rendah dibanding inflasi pada periode dummy, meski tidak memiliki pengaruh nyata.

Tabel 1.

\section{Estimasi Inflasi Model Autoregressive}

\begin{tabular}{|c|c|c|c|c|}
\hline \multicolumn{5}{|c|}{ 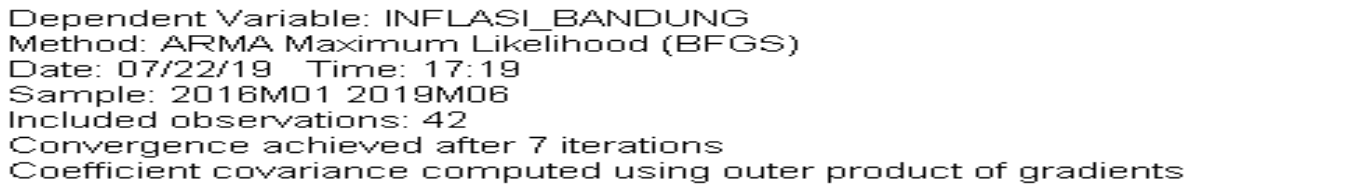 } \\
\hline Variable & Caefficient & Std. Errar & t-Statistic & Prob. \\
\hline $\begin{array}{c}\text { C } \\
\text { DUMMYOTREND } \\
\text { AR(1) } \\
\text { SIGMASQ }\end{array}$ & $\begin{array}{r}3.508370 \\
-0.007489 \\
0.744329 \\
0.136731\end{array}$ & 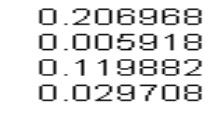 & $\begin{array}{r}16.95128 \\
-1.265468 \\
6.208838 \\
4.602440\end{array}$ & $\begin{array}{l}\text { ‥ } 0000 \\
\text { ․2134 } \\
\text { ‥0000 } \\
\text { ‥0000 }\end{array}$ \\
\hline $\begin{array}{l}\text { R-squared } \\
\text { Adjusted F-squared } \\
\text { S.E. of regression } \\
\text { Sum squared resid } \\
\text { Log likelihood } \\
\text { F-statistic } \\
\text { Prob(F-Statistic) }\end{array}$ & $\begin{array}{r}0.510832 \\
0.472214 \\
0.388746 \\
5.742681 \\
-18.21455 \\
13.22765 \\
0.000005\end{array}$ & \multicolumn{2}{|c|}{$\begin{array}{l}\text { Mean dependent var } \\
\text { S.D. dependent var } \\
\text { Akaike info criterion } \\
\text { Schwarz criterian } \\
\text { Hannan-Quinn criter. } \\
\text { Durbin-Watson Stat }\end{array}$} & $\begin{array}{l}3.446700 \\
0.535102 \\
1.057838 \\
1.223328 \\
1.118495 \\
1.950848\end{array}$ \\
\hline Inverted AF Foots & .14 & & & \\
\hline
\end{tabular}

Sumber: Hasil Estimasi Penulis 
Gambar 5.

Proyeksi Inflasi Kota Bandung (y-o-y)

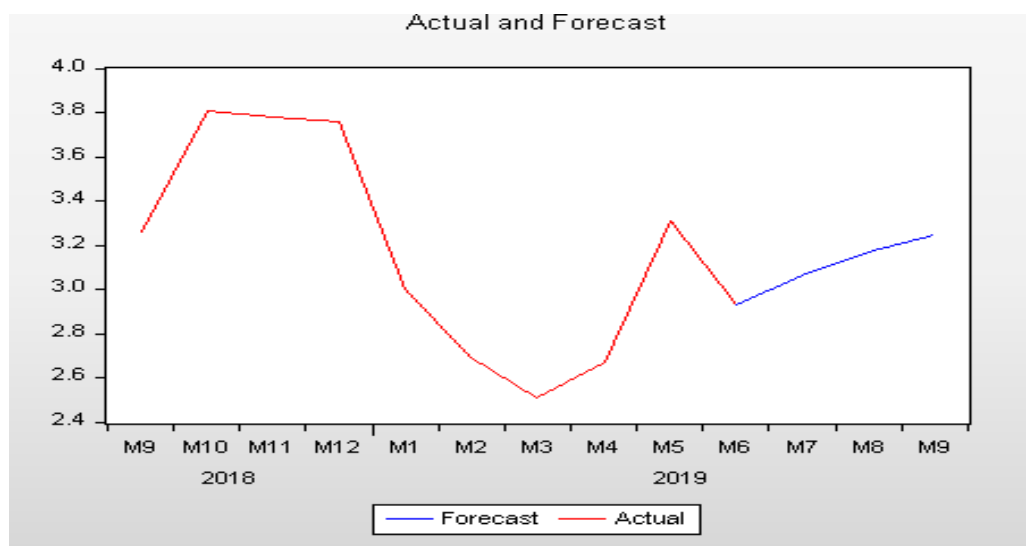

Sumber: Hasil estimasi penulis

Berdasarkan hasil estimasi inflasi model AR, diketahui bahwa periode Juli, Agustus, September,inflasi Kota Bandung (y-o-y) diprediksikan berkisar antara 3,07\% - 3,26\%. Diprediksikan meningkat dibanding periode Juni 2019. Namun peningkatan tersebut lebih kecil dibanding dengan laju inflasi pada periode yang sama tahun 2018. Prediksi kenaikan inflasi tersebut dinilai wajar mengingat kenaikan inflasi mengikuti pola seasonal yakni puncak musim kemarau pada JuliSeptember 2019, yang berpotensi mengakibatkan terganggunya pasokan terutama komoditas pangan, yang dapat memicu gejolak harga.

Indikator laju pertumbuhan ekonomi (LPE) memiliki data yang relatif kurang terkini jika dibandingkan dengan indikator inflasi. Data terbaru yang ada adalah laju pertumbuhan ekonomi tahun 2017. LPE Kota Bandung Tahun 2017 sebesar 7.21\%, turun cukup signifikan jika dibanding dengan LPE 2016. Selain itu, capaian LPE 2017 juga merupakan yang terendah sejak tahun 2011. Penurunan kondisi ekonomi global patut diduga menjadi salah satu faktor penyebab relatif rendahnya LPE Kota Bandung, melalui jalur penurunan ekspor produk industri 
pengolahan. Berdasarkan data Kota Bandung Dalam Angka (2018), aktivitas industri pengolahan di Kota Bandung banyak didominasi oleh aktivitas industri tekstil dan pakaian jadi. Hal tersebut terlihat dari jumlah perusahaan yang beroperasi pada kedua sub-sektor tersebut sebanyak 246 perusahaan (menengah besar) atau $48 \%$ dari total perusahaan menengah besar yang ada di Kota Bandung. Dengan pelemahan kondisi ekonomi global, maka permintaan ekspor produk tekstil dan pakaian jadi juga menurun sehingga berdampak pada kinerja industri pengolahan dan akhirnya berkontribusi pada penurunan laju pertumbuhan ekonomi.

Gambar 6.

Laju Pertumbuhan Ekonomi Kota Bandung

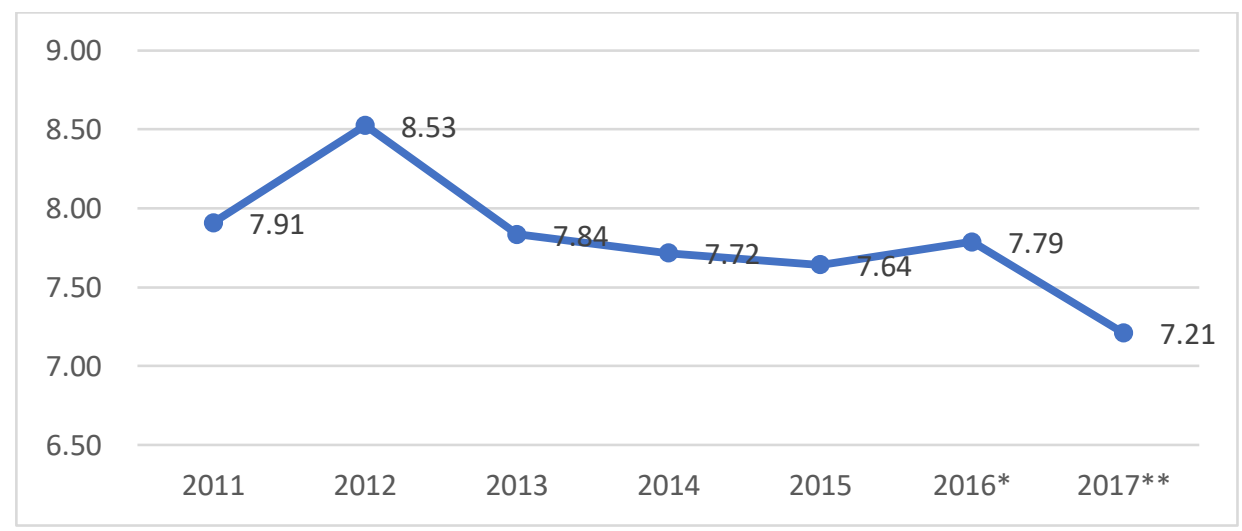

Sumber: Badan Pusat Statistik Kota Bandung, 2019, diolah

Dari sisi laju pertumbuhan sektoral, pertumbuhan yang tinggi banyak didominasi oleh sektor tersier seperti sektor transportasi dan pergudangan, sektor telekonomunikasi, penyediaana akomodasi makan minum dan sektor jasa pendidikan dan kesehatan. Sementara itu, sektor primer dan sektor sekunder seperti pertanian, industri pengolahan dan perdagangan, masih menunujukkan kinerja pertumbuhan yang positif, namun tidak sepesat pertumbuhan ekonomi sektor tersier. Hal ini menunjukkan, dari sisi pertumbuhan sektoral, terdapat potensi 
pergeseran struktur ekonomi dari sektor primer-sekunder menuju sektor tersier. Kondisi tersebut juga dapat dilihat dari kontribusi sektoral terhadap PDRB.

Gambar 7.

Laju Pertumbuhan Ekonomi Sektoral, PDRB Harga Konstan 2010

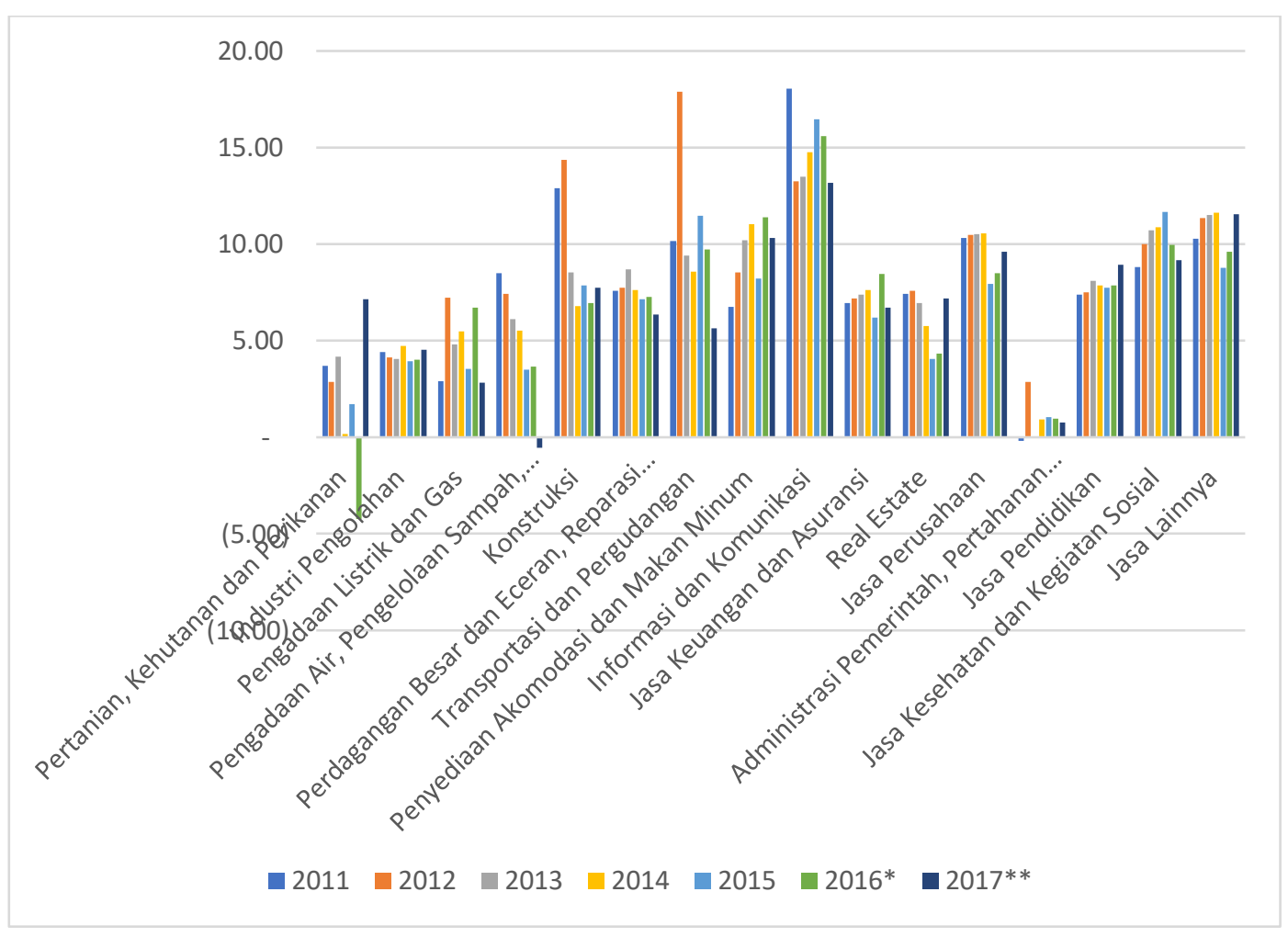

Sumber: Badan Pusat Statistik Kota Bandung, 2019 diolah

Gambar 8 menunjukkan kontribusi sektoral terhadap PDRB Kota Bandung tahun 2011-2017. Sektor Industri Pengolahan sebagai sektor dengan kontribusi terbesar kedua menunjukkan kontribusi yang terus menurun sejak tahun 2011. Sektor Perdagangan Besar dan Eceran, Reparasi Mobil dan Sepeda Motor sebagai sektor dengan kontribusi terbesar menunjukkan kontribusi yang relatif konstan sejak 2011, bahkan cenderung sedikit menurun sejak 2013-2017. Sektor dengan kontribusi yang terus menunjukkan peningkatan adalah sektor informasi dan 
komunikasi, seiring dengan perkembangan ekonomi digital dan sharing economy. Juga Hal ini menunjukkan adanya indikasi pergeseran struktur perekonomian.

\section{Gambar 8.}

\section{Kontribusi Sektoral Terhadap PDRB Harga Konstan 2010}

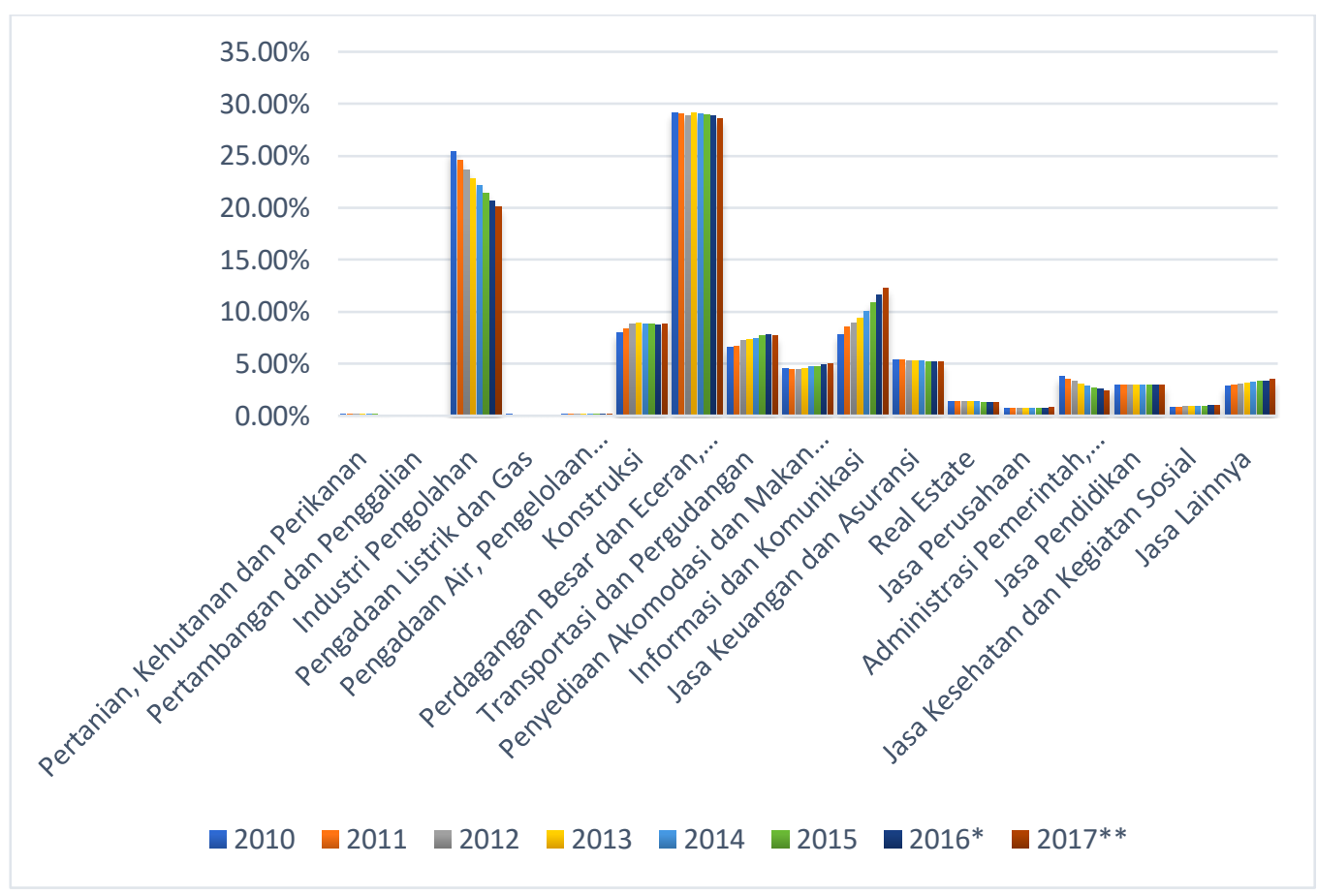

Sumber: Badan Pusat Statistik Kota Bandung, 2019 diolah

Perkembangan ketenagakerjaan dapat dilihat dari dua indikator utama, yakni Tingkat Partisipasi Angkatan Kerja (TPAK) dan Tingkat Pengangguran Terbuka (TPT) Tabel 1 menunjukkan perkembangan indikator ketenagakerjaan di Kota Bandung selama tahun 2010-2018. Dari Tabel 2, dapat dilihat bahwa TPAK di Kota Bandung tetap konsisten di level 61-63\%. TPAK tertinggi terjadi pada tahun 2013 sebesar $63.61 \%$. Sementara itu, TPT cenderung berfluktuasi antar periode. TPT terendah terjadi pada tahun 2014 pada level 8,05\% sementara tertinggi pada level $12,16 \%$. 
Tabel 2.

Indikator Ketenagakerjaan Kota Bandung 2010-2018

\begin{tabular}{|c|c|c|c|c|}
\hline Tahun & $\begin{array}{l}\text { Jumlah Angkatan } \\
\text { Kerja }\end{array}$ & TPAK $(\%)$ & Pengangguran & TPТ $(\%)$ \\
\hline 2010 & 1.079 .477 & 60,73 & 131.353 & 12.16 \\
\hline 2011 & 1.129 .744 & 61,40 & 116.798 & 10,34 \\
\hline 2012 & 1.171 .551 & 63,14 & 107.384 & 9,17 \\
\hline 2013 & 1.176 .377 & 63.61 & 129.142 & 10,98 \\
\hline 2014 & 1.192 .770 & 63.04 & 95.971 & 8,05 \\
\hline 2015 & 1.192 .521 & 62.52 & 107.532 & 9,02 \\
\hline 2016 & - & - & - & - \\
\hline 2017 & 1.219 .398 & 63.11 & 102.869 & 8,44 \\
\hline 2018 & & 62.92 & & 8,17 \\
\hline
\end{tabular}

Sumber:BPS Kota Bandung

Jika dilihat penyebaran tenaga kerja berdasarkan sektor usaha, dapat dilihat pada Gambar 9. Dilihat dari Gambar 9 bahwa penduduk yang bekerja, sebagain besar bekerja pada sektor perdagangan besar, eceran, hotel dan restoran. Penduduk yang bekerja pada sektor tersebut juga meningkat pada tahun 2017 dibanding tahun 2015. Pada tahun 2017, penduduk yang bekerja disektor perdagangan besar, eceran, hotel dan restoran juga merupakan yang tertinggi dibanding periode sebelumnya. Kemudian, sektor yang banyak menyerap tenaga kerja adalah sektor industri pengolahan dan jasa kemasyarakatan. Khusus untuk sektor industri pengolahan, menunjukkan adanya penurunan penyerapan tenaga kerja sejak tahun 2013 hingga 2017.Sementara sektor jasa kemasyarakatan, sosial dan perorangan cenderung berfluktuasi selama periode observasi. 
Gambar 9.

Persentase Penduduk Bekerja Berdasarkan Lapangan Usaha

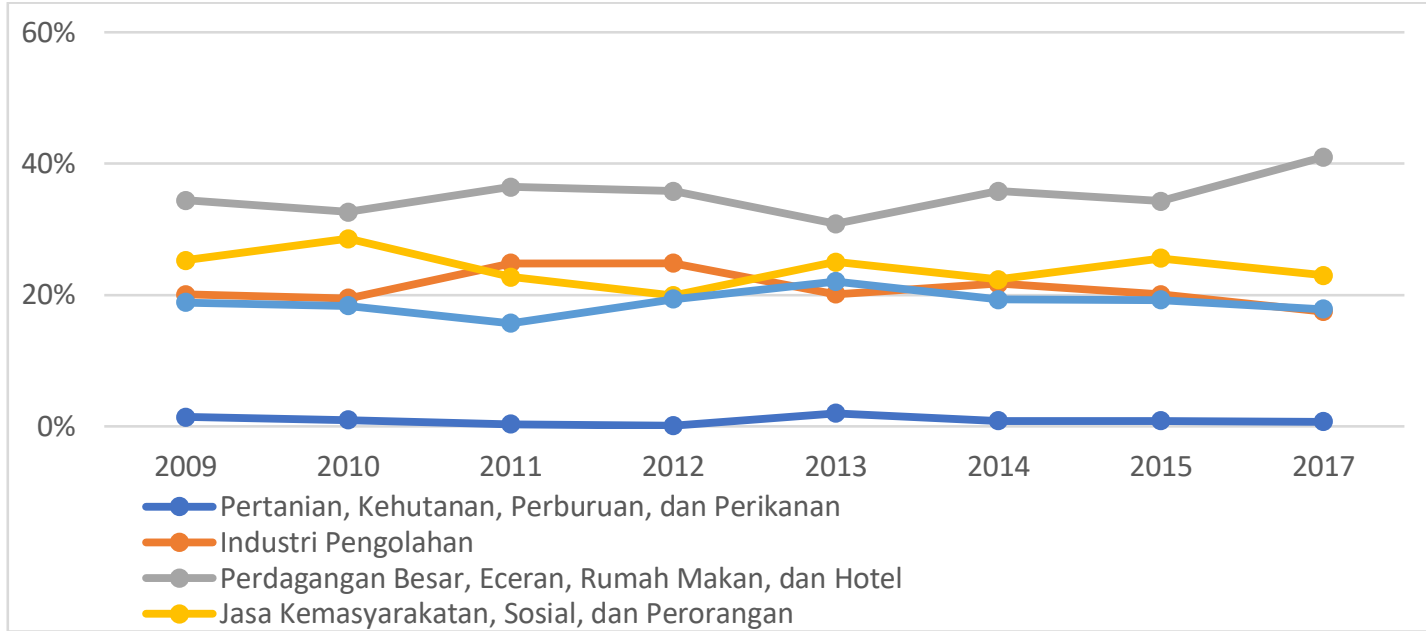

Sumber: BPS Kota Bandung, diolah

Untuk melihat lebih detail terkait indikator ketenagakerjaan, dapat dikaitkan dengan pertumbuhan ekonomi. Gambar 10 dan 11 menunjukkan hubungan antara TPAK dan Laju Pertumbuhan Ekonomi (LPE).

Gambar 10.

TPAK, dan Laju Pertumbuhan Ekonomi Kota Bandung 2011-2017

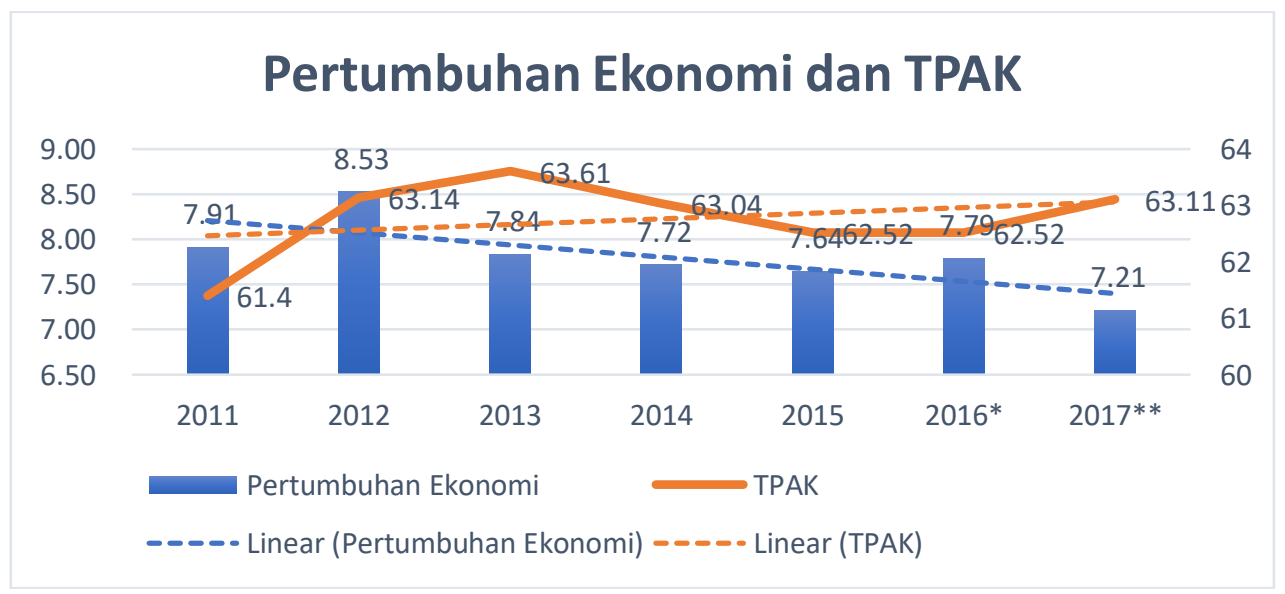

Sumber: BPS Kota Bandung, diolah

Gambar 10 menunjukkan bahwa terdapat arah hubungan yang berbeda antara TPAK dan pertumbuhan ekonomi. Seyogyanya antara TPAK dan LPE 
memiliki korelasi yang posifitif. Namun berdasarkan uji korelasi yang dilakukan, menunjukkan koefisien yang negatif sebesar -0.02. Jika dilihat dari trend perkembangan TPAK, menunjukkan arah yang positif, sementara trend pertumbuhan ekonomi menurun. Hal ini menunjukkan tidak ada kaitan yang kuat antara TPAK dengan pertumbuhan ekonomi, baik dari kekuatan maupun arah hubungan. Jika dikaitkan dengan TPT, laju pertumbuhan ekonomi justru positif, yang mana seyogyanya negatif. Koefisien korelasi juga cukup kuat sebesar 0.3,

Gambar 11.

TPAK, dan Laju Pertumbuhan Ekonomi Kota Bandung 2011-2017

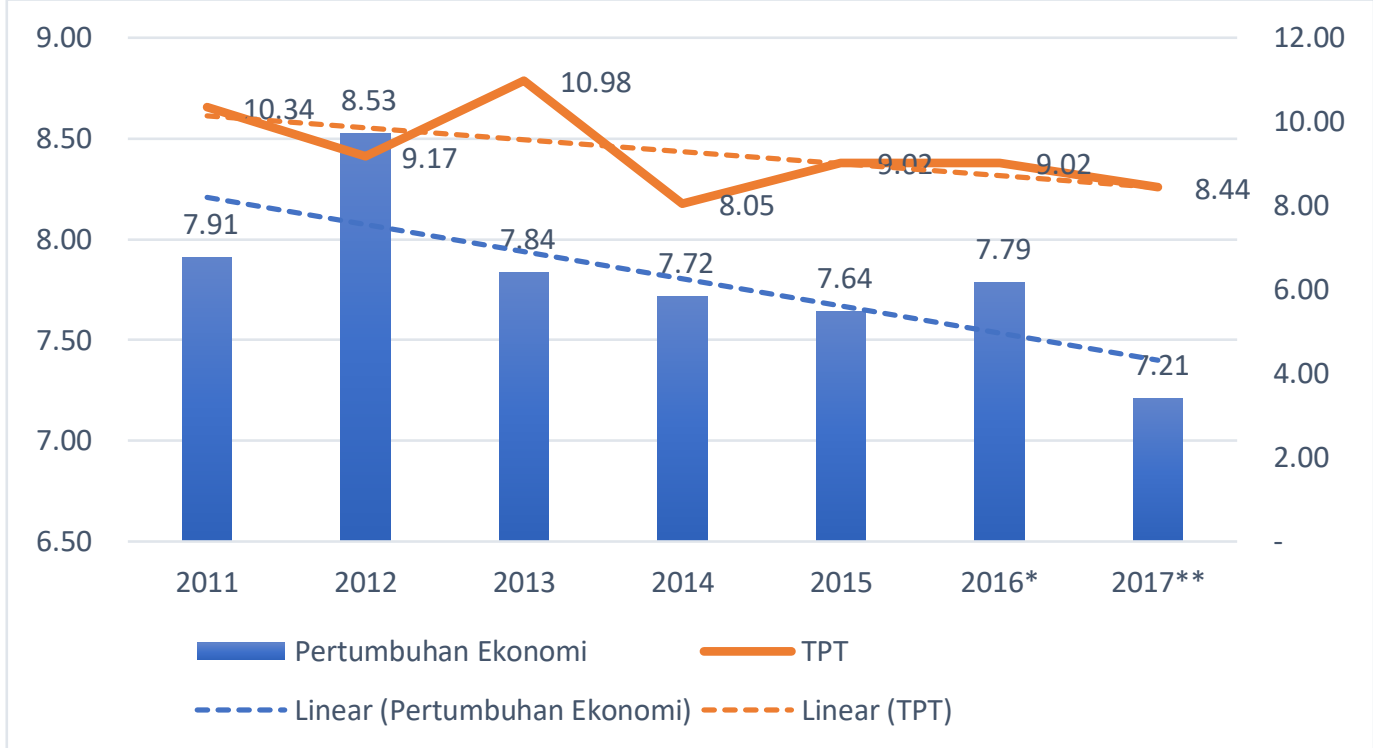

Hal tersebut juga sekaligus mengkonfirmasi tidak ada hubungan yang relevan antara pertumbuhan ekonomi dengan kualitas penyerapan tenaga kerja. Namun, antara indikator TPAK dan TPT sudah menunjukkan arah yang relevan, dimana terdapat korelasi negatif sebesar -0.13 , artinya kenaikan TPAK memiliki konsekuensi penurunan TPT. Sebagaimana disajikan dalam Tabel 3 berikut: 
Tabel 3.

Korelasi TPT, TPAK dan LPE Kota Bandung

\begin{tabular}{lrrrr}
\hline & & & \multicolumn{2}{c}{ TPAK } \\
\hline LPE & 1.00 & 0.30 & -0.02 \\
TPT & 0.30 & 1.00 & -0.13 \\
TPAK & -0.02 & -0.13 & 1.00 \\
\hline BPS Kota Bandung, diolah & & & &
\end{tabular}

Kualitas pertumbuhan dan penyerapan tenaga kerja juga dapat dilihat dari korelasi antara pertumbuhan sektoral dengan penyerapan tenaga kerja. Gambar 12 menunjukkan arah hubungan antara pertumbuhan industri pengolahan dan penyerapan tenaga kerjanya. Diketahui bahwa pertumbuhan pada industri pengolahan memiliki korelasi negatif sebesar $-0.58 \%$ dengan penyerapan tenaga kerja sektor tersebut. Trend penyerapan tenaga kerja menurun, meski pertumbuhan sektor industri naik. Hal ini menjadi indikasi bahwa meski terjadi pertumbuhan produksi, namun tidak diikuti dengan penambahan pemanfaatan tenaga kerja. Artinya, terdapat indikasi substitusi input dari tenaga kerja ke modal maupun teknologi.

Gambar 12.

Pertumbuhan Industri Pengolahan dan Penyerapan Tenaga Kerja

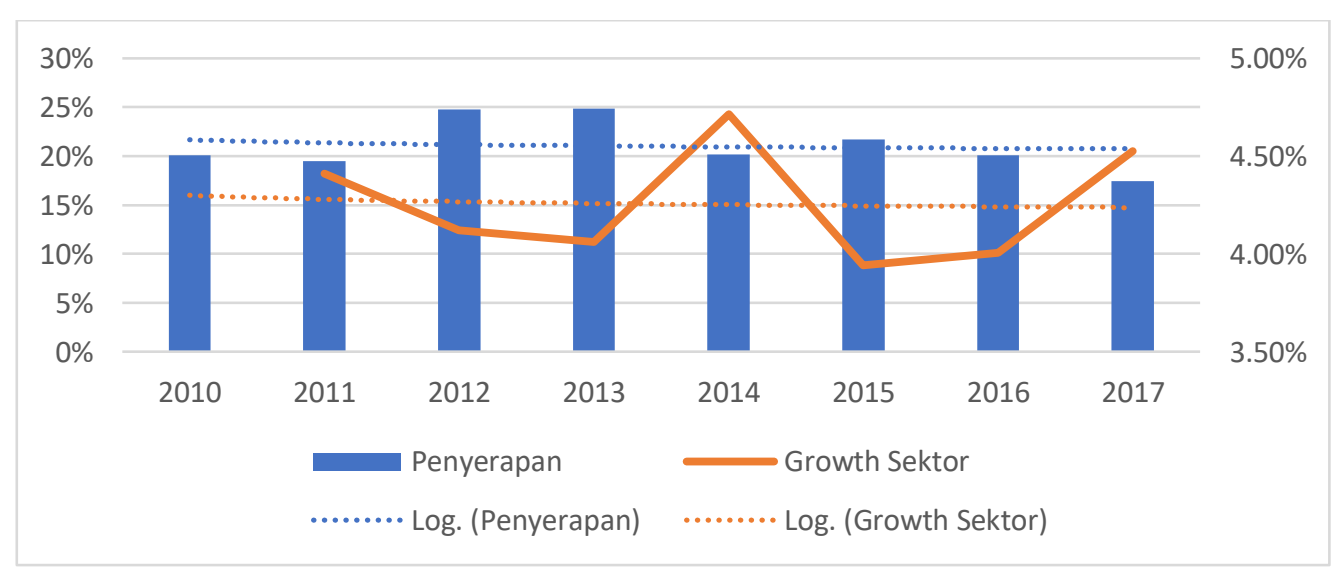

Sumber: BPS Kota Bandung, diolah 
Pada sektor Perdagangan Besar, Eceran, Rumah Makan, dan Hotel, terdapat juga korelasi yang negatif antara penyerapan tenaga kerja dengan pertumbuhan sektoral, dengan korelasi yang kuat -0.73. Meski demikian, kita dapat memaknai dari trend masing-masing indikator. Gambar 12 menunjukkan arah hubungan pertumbuhan sektor dengan penyerapan tenaga kerja. Dari Gambar 13 menunjukkan hal yang menarik, dimana meski pertumbuhan sektoral turun, namun penyerapan tenaga kerja justru naik. Hal tersebut mengindikasikan bahwa sektor Perdagangan Besar, Eceran, Rumah Makan, dan Hotel yang cenderung bersifat informal justru dapat menyerap tenaga kerja lebih meski pertumbuhan sektornya menurun.

Gambar 13.

Pertumbuhan Sektor dagangan Besar, Eceran, Rumah Makan, dan Hotel dan Penyerapan Tenaga Kerja

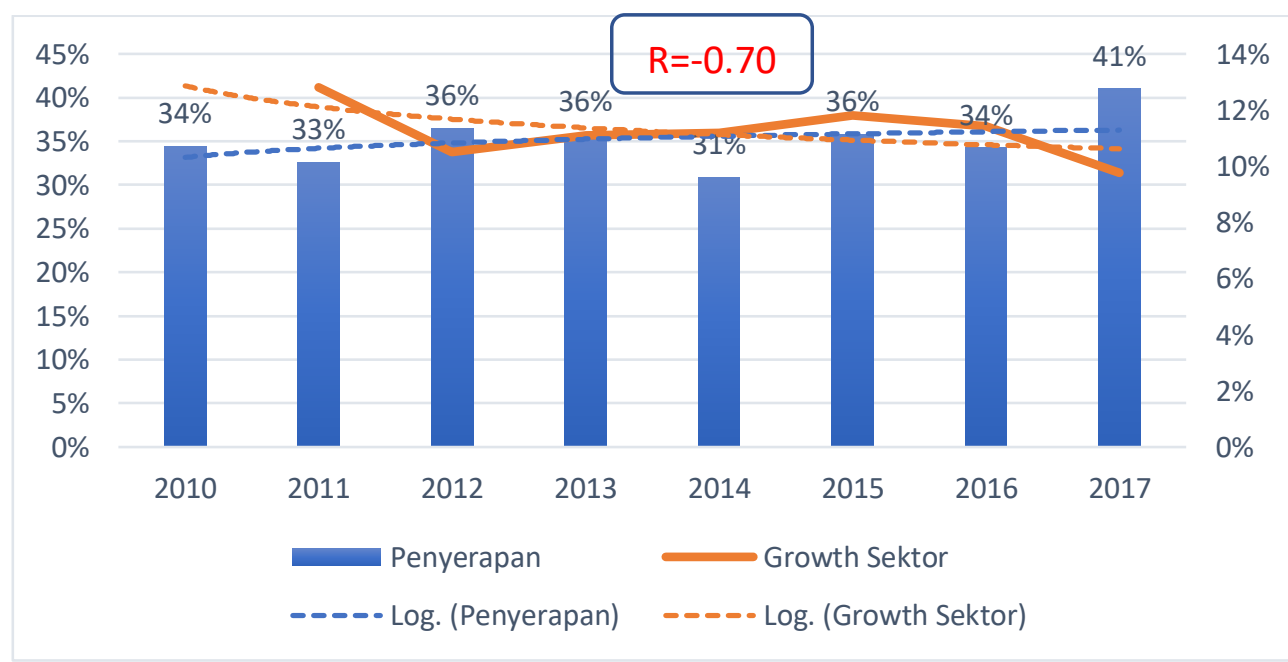

Sumber: BPS Kota Bandung, diolah 


\section{SIMPULAN}

Berdasarkan 3 (tiga) indikator makro yang diamati, kesimpulan dari analisis yang dilakukan sebagai berikut:Inflasi di Kota Bandung secara umum rendah dan terkendali pada kuartal II-2019. Bahkan capaian inflasi Kota Bandung lebih rendah dibanding inflasi Nasional dan Jawa Barat. Meski sempat meningkat pada Bulan Mei 2019 karena memasuki periode Ramadhan dan Idul Fitri, namun pada bulan Juni inflasi menunjukkan penurunan. Dibanding Kota IHK di Jawa Barat, laju inflasi di Kota Bandung lebih rendah dibanding Kota Bekasi, Kota Depok dan Kota Bogor. Namun demikian, meski inflasi secara umum terjaga, namun masi menyisakan permasalahan gejolak harga pangan. Utamanya komoditas cabai yang melonjak sangat signifikan mencapai diatas Rp. 80.000,-/kg. Keterbatasan pasokan akibat musim kemarau membuat harga cabai meningkat signifikan.

Pertumbuhan Ekonomi Kota Bandung dengan data terakhir tahun 2017 menunjukkan penurunan menjadi $7.21 \%$ dibanding periode sebelumnya $7.69 \%$. Capaian pertumbuhan ekonomi tersebut juga merupakan yang terendah sejak tahun 2011. Faktor pelemahan ekonomi global patut diduga menjadi salah satu faktor penyebab penurunan pertumbuhan ekonomi, melalui dampaknya terhadap penurunan kinerja industri pengolahan yang didominasi oleh industri tekstil dan pakaian jadi, yang memiliki orientasi ekspor. Namun, tentu saja diperlukan kajian lebih mendalam untuk melihat faktor penurunan pertumbuhan ekonomi di Kota Bandung tersebut.

Kontributor sektoral terhadap PDRB Kota Bandung masih di dominasi oleh sektor Perdagangan Besar, Eceran, Reparasi Mobil dan Sepeda Motor dan Industri 
Pengolahan. Namun demikian, kontribusi sektor industri pengolahan terhadap PDRB terus menurun. Hal ini menjadi indikasi bahwa aktivitas ekonomi mulai bergeser dari aktivitas sekunder ke aktivitas tersier.

Terjadi penurunan tingkat pengangguran terbuka di Kota Bandung pada 2018. penduduk yang bekerja, sebagain besar bekerja pada sektor perdagangan besar, eceran, hotel dan restoran. Penduduk yang bekerja pada sektor tersebut juga meningkat pada tahun 2017 dibanding tahun 2015. Pada tahun 2017, penduduk yang bekerja disektor perdagangan besar, eceran, hotel dan restoran juga merupakan yang tertinggi dibanding periode sebelumnya. Kemudian, sektor yang banyak menyerap tenaga kerja adalah sektor industri pengolahan dan jasa kemasyarakatan.

Tidak terdapat hubungan yang relevan antara Laju Pertumbuhan Ekonomi, TPT dan TPAK. Jika dilihat dari trend perkembangan TPAK, menunjukkan arah yang positif, sementara trend pertumbuhan ekonomi negatif. Hal ini menunjukkan tidak ada kaitan yang kuat antara TPAK dengan pertumbuhan ekonomi, baik dari kekuatan maupun arah hubungan. Jika dikaitkan dengan TPT, laju pertumbuhan ekonomi justru positif, yang mana seyogyanya negatif.

\section{REFERENSI}

(2018). Perhitungan dan Analisis Kemiskinan Makro Indonesia Tahun 2018. Badan Pusat Statistik, Jakarta.

Badan Pusat Statistik Kota Bandung. (2018). Indikator Ketenagakerjaaan 2011 2017 Kota Bandung. Badan Pusat Statistik Kota Bandung, Bandung.

Badan Pusat Statistik Kota Bandung. (2018). Kota Bandung Dalam Angka. Badan Pusat Statistik Kota Bandung, Bandung. 
Badan Pusat Statistik Kota Bandung. (2018). Produk Domestik Regional Bruto Kota Bandung Menurut Lapangan Usaha. Badan Pusat Statistik Kota Bandung, Bandung.

Badan Pusat Statistik Kota Bandung. (2019). Indeks Harga Konsumen dan Perubahannya Berdasarkan Kelompok Pengeluaran. Badan Pusat Statistik Kota Bandung, Bandung.

Badan Pusat Statistik Provinsi Jawa Barat (2019). Berita Resmi Statistik: Perkembangan Indeks Harga Konsumen. No. 34/07/32/Th. XXI, 1 Juli 2019

Badan Pusat Statistik Provinsi Jawa Barat. (2018). Produk Domestik Regional Bruto Provinsi Jawa Barat Menurut Lapangan Usaha. Badan Pusat Statistik Provinsi Jawa Barat, Bandung.

Badan Pusat Statistik. (2017). Data dan Informasi Kemiskinan Kabupaten/Kota Tahun 2016. Badan Pusat Statistik, Jakarta.

Da Silva, Sergio (2009). Does Macroeconomics Need Microeconomic Foundations? Economics: The Open-Access, Open-Assessment E-Journal, 3 (2009-23): 1-12.

Enders, Walter. (2009). Applied Econometric Time Series $3^{\text {rd }}$. New York: John Wiley \& Sons, Inc.

Hubbard, Glenn (2016). Macroeconomics. 6 edition . Pearson Eduation . ISBN-13: 2900134106228

Necati, Tekatli, (2010). A New Core Inflation Indicator for Turkey (Turkiye Ekonomisi Icin Yeni Bir Cekirdek Enflasyon Gostergesi)," Working Papers 1019, Research and Monetary Policy Department, Central Bank of the Republic of Turkey. 